\title{
Developing Multiple Intelligences Using Films in Primary Education
}

\author{
Alonso Mateo Gómez* Pilar Valera García \\ Faculty of Education, Castilla La Mancha University, Pza. de la Universidad, 3. 02071 Albacete, Spain \\ E-mail of the corresponding author: Alonso.Mateo@uclm.es
}

\begin{abstract}
The aim of this paper is to provide an interdisciplinary project based on the theory of multiple intelligences proposed by Howard Gardner, using films as a means to achieve the motivation needed for pupils to learn significatively. This article tries to help teachers to confront the demanding task of easing the necessities of nowadays society. The project is proposed for the English subject through in an interdisciplinary perspective. In this case, a short-term project, comprising ten sessions, is proposed. The proposal includes the activities to be worked out and their corresponding evaluation instruments. The topic is based on the film 'Zootopia' produced by Walt Disney Animation Studios with the objective of developing the eight multiple intelligences.
\end{abstract}

Keywords: multiple intelligences, films, interdisciplinary, English, motivation.

DOI: $10.7176 / \mathrm{JEP} / 11-3-02$

Publication date: January $31^{\text {st }} 2020$

\section{Introduction}

This work presents an innovation project within the theoretical framework of the theory proposed by Howard Gardner (1993). For that purpose, multiple intelligences (MI) are worked up through an animation film called 'Zootopia'. This proposal combines, therefore, the MI approach with the use of films. According to Armstrong (2009) "MI theory is valuable because it provides teachers with the means to sort through strategies... and discipline systems and offers guidelines for selecting a limited number of interventions to try out based upon the student's individual differences" (p.120). We tend to think that someone is intelligent if this person is brilliant at mathematics, languages or physics. However, teachers should develop different kind of skills which will make pupils intelligent in every field, as we can be intelligent in the field of nature, but we may fail subjects such as English or mathematics, as explained by Howard Gardner (1993).

By carrying out these types of projects, we could develop any content from any subject taught during the primary education stage. In this proposal, pupils from the fourth grade of primary education will learn contents from English, natural sciences, artistic education, physical education and social and civic values.

\section{Multiple intelligences theory by Howard Gardner}

2.1 What is the intelligence, according to Gardner?

Gardner (1999), proposed a detailed definition of intelligence, he gave us this definition: "a biopsychological potential to process information that can be activated in a cultural setting to solve problems or create products that are of value in a culture" (p.33-34). Using this category of "potentials", he is displaying that intelligence is something abstract, that cannot be seen, it is not something concrete, moreover, he is showing us that these potentials could not be initiated or stimulated depending on the context, the situation, the things or people we are surrounded by.

\subsection{The different intelligences proposed by Gardner}

Thomas Armstrong (2009), basing his knowledge on the publications of Howard Gardner, defines eight multiple intelligences:

Linguistic intelligence: this intelligence exposes the capacity of using words orally and in writing in a correct way, it is also related to the use of syntax, pragmatics, phonology, semantics, some of the uses could be in rhetoric, explanation, mnemotechny techniques and metalanguage.

Logical-Mathematical intelligence: this intelligence reveals the capacity of using numbers, reasoning, understanding patterns, logics, propositions and statements, functions and other type of abstractions such as categorization, classification, deduction, generalization, calculus and hypothesis.

Spatial Intelligence: this intelligence proves the ability of recognizing the visual-spatial world, in which we distinguish colours, lines, shapes, the space and its relationships, being capable of making transformations based on the perceptions. Moreover, it involves the capacity of visualising and representing ideas graphically, but also, orienting yourself in the space.

Bodily-Kinesthetic Intelligence: this intelligence entails the ability of controlling our own body in order to express feelings or ideas, but also, using our hands to create products. In consequence, it involves coordination, equilibrium, strength, flexibility, technical abilities and speed, including haptical abilities. 
Musical Intelligence: this intelligence results in the ability of perceiving, distinguishing, transforming and expressing different musical figures. Rhythm, melody and timbre are also characteristics that are perceived in this type of intelligence.

Interpersonal Intelligence: this intelligence concerns the capacity of recognizing other people's mood, their intentions, motivations and feelings. Furthermore, it comprises the capacity of differentiating interpersonal signals and responding correctly to them.

Intrapersonal Intelligence: this intelligence refers to the ability of knowing yourself, being aware of your own intentions, wishes, motivations, mood, self-esteem, in conclusion, having an accurate image of yourself.

Naturalist Intelligence: this intelligence exposes the capacity of classifying and detecting animal and flora species, as well as other natural phenomena but also inanimate things.

\section{Definition of film}

\subsection{Film at school}

Blasco, P. G., Moreto, G., Blasco, M. G., Levites, M. R., \& Janaudis, M. A. (2015) asume that "cinema is the audiovisual version of storytelling. It enhances emotions and therefore sets up the foundation for conveying concepts. Movie experiences act like emotional memories for developing attitudes and keeping them as reflective reference in the daily activities and events".

As Kabooha (2016) proves in the study that was developed, films are an effective strategy to teach languages, promoting motivation between the students, and in consequence, their participation in the classroom. However, the films should be adapted to any grade, and objectives, planning pre-watching and post-watching activities, in order to be meaningful learning.

Moreover, Breu \& Ambrós (2011) explains films as a key to teaching social values in a cross curricular and interdisciplinary way. Not only films are helpful to teach social values but also to promote humanizing values to learn about ourselves as part of our identity. The motivation produced by films is the starting point to work any content at school. Film is a cultural field that should be in the classrooms. But also, films make us develop our critical sense, it affects us in such a way that we create our own points of view, we value and reflect about the world. The possibilities film provides us in the educative field are infinite, for instance, not only can we use it to reflect and develop social values, but we can also use its script to work the reading comprehension and analyse the vocabulary.

\subsection{Animated film}

Żebrowski (2017) expresses his agreement with Karol Irzykowski about the designation of animation film as art because of its individual personality.

"If we agree with Irzykowski's opinion, based on the versatility of animation and its potential for exploring the artistic opportunities offered by films (1924, pp. 212, 218), it should logically follow that, apart from its aesthetic and artistic merits, animation provides a perfect tool for education regarding animation itself, but also cinema in broad terms". (Żebrowski, 2017, p.106)

Roger Eber (1998), talking about the film Mulan, finds, as well as Żebrowski (2017), animation as an art that awakens his imagination removing the part of reality live-action films provide. (Cited in Champoux, 2005)

Furthermore, as Kenna (2017) specifies, not only do primary education students enjoy watching animated film, but middle and high school students do also like watching these types of film.

Kenna (2017) remarks: "Therefore, we hope teachers will strongly consider the powerful methods of using animated film as a springboard for leading discussions or inquiries and as an organizational tool for teaching geography” (p.151).

\section{Method}

The methodology applied in this proposal is based on participative and active lessons, promoting scaffolding and interdisciplinary teaching, aiming significant learning. This is specified through project-based learning, which is a teaching methodology that helps students to acquire skills and knowledge by working, researching and discovering about a topic, usually based in real-life situations.

Among the methodological strategies, we focus on cooperative learning, "Cooperation is structured by creating positive interdependence among individuals' goal attainments; individuals perceive that they can reach their goals if and only if the other individuals in the situation also reach their goals" (Johnson \& Johnson, 1999, p.4). These authors establish five basic elements in cooperative learning. The first is positive interdependence, which is related to the objectives. The goal is only achieved if everybody works, so everyone benefits everyone. The second one is the individual accountability; the team is assessed as a group but also as individuals. The third one is the social skills which should be taught in order to use them, so the more social skills they learn, the better results. The fourth one is group processing, which is based on reflecting about the member actions sense to achieve goals and keep working relationships and to make decisions about possible changes in those actions (Johnson \& 
Johnson, 1999).

The cooperative learning methodology is, as Alghamdy (2019) states, a source of improvement on the academic results of students who work cooperatively. In his article, there are students' opinions about cooperative learning and its results after having been taught using this methodology: "In general, most students found that CL enabled them to improve their English skills, make new relationships with other classmates, perform different roles, improve their oral presentation skills, build their self-confidence, take on responsibility, respect different opinions and offer their different views, increase their motivation, and develop their friendships with their classmates". (Alghamdy, 2019, p.276)

This methodology is closely related to the interpersonal intelligence proposed by Gardner. As cooperative learning entails "positive interdependence among individuals" (Johnson \& Johnson, 1999, p.4), it develops what Armstrong (2009) explains as working in groups, knowing each other, recognizing other people's mood, their intentions, motivations and feelings, it means, the interpersonal intelligence.

Another methodology to be implemented is Content and Language Integrated Learning (CLIL), which, according to Breeze $(2014$, p. 56). "is different from traditional language learning because it combines language learning with content learning".

As Coyle et al. (2010) note, when CLIL is used, language is learnt in a meaningful way, because it is based on the pupils' context (Cited in Breeze, 2014). Furthermore, Gatbonton \& Segalowitz (2005) assumes that the goal in this methodology is communication, it is not the language, but maintaining communication in factual situations (Cited in Breeze, 2014).

"One of the main advantages of CLIL is that the language becomes a tool for communication, and this has important implications for how it needs to be dealt with" (Breeze, 2014, p.1).

The CLIL methodology can be related to the linguistic intelligence, whereas English is being practiced in its linguistic form. Since CLIL methodology implies, as Breeze (2014) states, using a language for communication, it does not only develop the linguistic intelligence, but it also develops the interpersonal intelligence.

Another method to be employed the total physical response (TPR), which, according to Zulpan (2018), is used to teach language through movement so, pupils should move or do any physical activity in order to follow the instructions of the teacher, and this is the cause of an increase in pupils' motivation when learning.

"In other words, TPR is a language teaching method built around the coordination of speech and action; it attempts to teach language through physical (motor) activity" (Zulpan, 2018, p.208).

The total physical response method is connected to the bodily-kinesthetic intelligence, as both concerns the movement in order to learn according to Zulpan (2018) and Armstrong (2009), it means, learning by moving, and the bodily-kinesthetic intelligence entails the ability of controlling our own body. However, the total physical response is often used to teach language as Zulpan (2018) points.

Complementary, the design thinking methodology is going to be applied, which is a pupil-centered method that takes into consideration pupils' interest and needs (Willness \& Bruni-Bossio, 2017). According to Hassi and Laakso (2011), this methodology is focused on a human-centred, collaboration, and holistic approach (Cited in Willness \& Bruni-Bossio, 2017).

"In terms of process, design thinking is iterative and characterized by prototyping (or experimentation) and visualization as a means of arriving at a solution to a problem (Brown, 2008a; Glen et al., 2014; Hassi \& Laakso, 2011). As Glen et al. (2014) explain, visualization involves graphics, sketches, and other imagery to express ideas as opposed to relying only on text, for instance. Visualization is an integral part of moving abstract thinking into fully formed ideas and mapping out a representation of the available information (Boni, Weingart, \& Evenson, 2009). Prototyping then involves making concepts and ideas into something concrete and exploring many possible solutions through a process of experimentation or "thinking by doing" (e.g., Hassi \& Laakso, 2011)" (Cited in Willness \& Bruni-Bossio, 2017, p.139)

As the design thinking methodology takes into account pupils' interests and needs (Willness \& Bruni-Bossio, 2017), it is correlated with the intrapersonal intelligence, which in accordance with Armstrong (2009), refers to the ability of knowing yourself, being aware of your own intentions, wishes, motivations, mood, self-esteem.

\section{Design of a proposal}

\subsection{Contextualization}

The target age of the students, considering that the activities proposed are for pupils whose native language is not English, could be nine or ten years old. We have to take into account that the final decision related to the age will be based on several contextual factors, like the number of previous years the students have been studying English, the foreign language level, the social background, etc. Therefore, considering that this project is proposed to be applied in a Spanish school, bearing in mind the mentioned factors, and in the case of the Spanish educational system, the design of this proposal is adjusted to pupils from fourth grade of primary education (9-10 years old children).

This proposal is an example of the interdisciplinary projects that teachers can carry out using the multiple 
intelligences theory and films. Contents from the subjects of English, natural sciences, physical education, civic and social values and artistic education are being developed through this project. Thus, it is needed coordination between the areas of all subjects carried on. In this way, the project can be developed successively during ten sessions.

\subsection{Proposal development}

This interdisciplinary project consists of ten sessions from the areas of natural sciences, English, social and civic values, physical education and artistic education for the fourth grade of primary education.

During the first session, an introduction to the film should be made. Teachers should consider the degree of acquisition of the different multiple intelligences so; pupils should take the test from Michael Berman (2002) to know what type of intelligence is better developed in their students. It is interesting to watch the trailer of the film and to analyse the plot and the characters.

The second session should be completed with the viewing of the film. In this way, the spatial intelligence is being developed during the first and second sessions.

For developing the logical-mathematical intelligence, pupils should create an end for the film, as some minutes from the film should be left. They should be creative and imagine whatever they want. At the end, every pupil would read their guesses and they could vote for the most original end during the third session. Thus, the design thinking methodology is being applied.

After watching the film, it is advisable for students to make a film review like in Figure 1 so, they develop the linguistic intelligence during session number four. In this case, the design thinking methodology is, as well, being implemented.

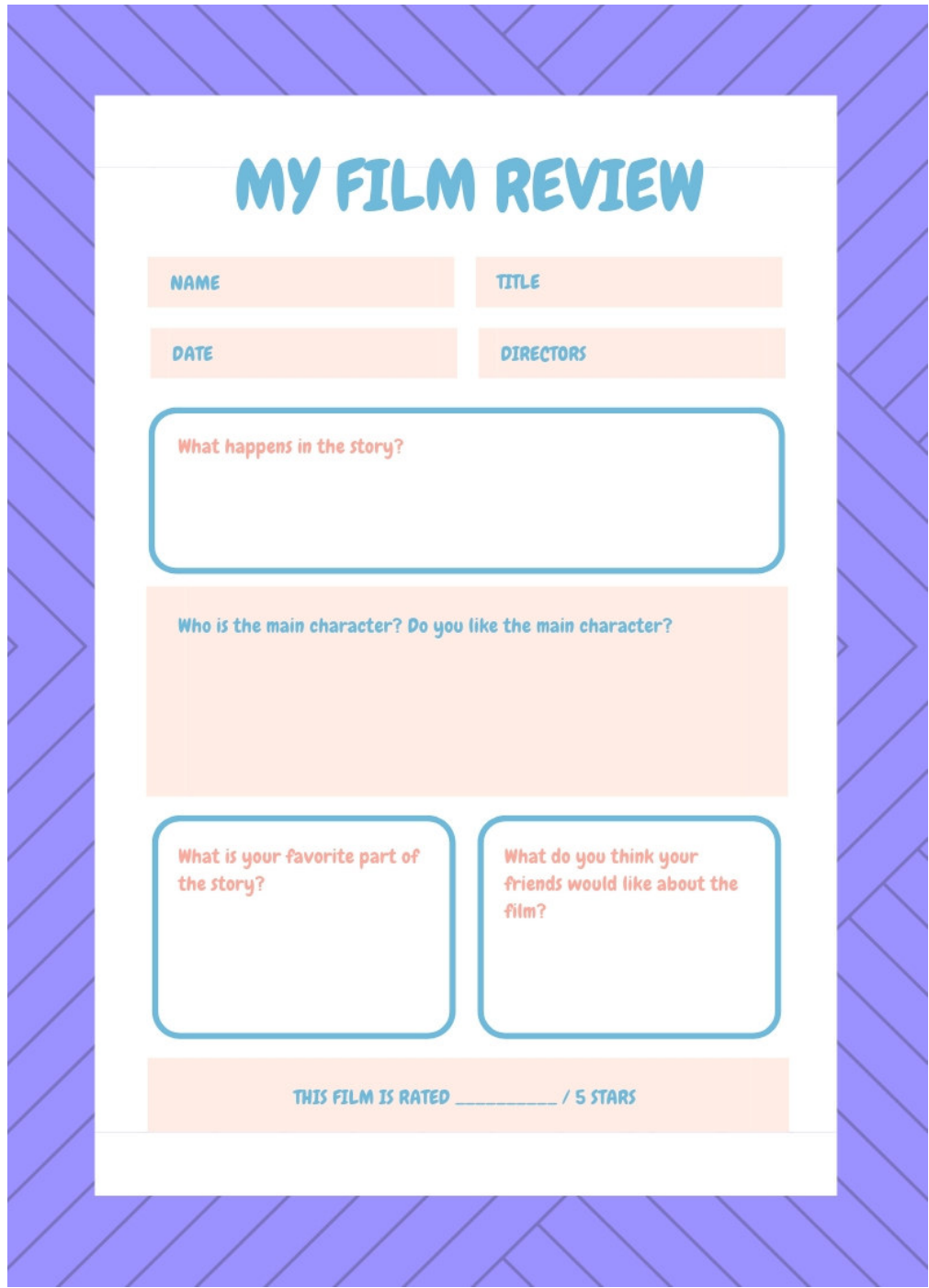

Figure 1. Film Review. The above figure shows a proposed film review for students to complete during the fourth session.

For the fifth session, in order to develop the linguistic and bodily-kinesthetic intelligences, students should 
answer the questions appearing in Figure 2 for describing their favourite animal appearing in the film, moreover, they should act as it. Therefore, the total physical response method is present throughout the session.

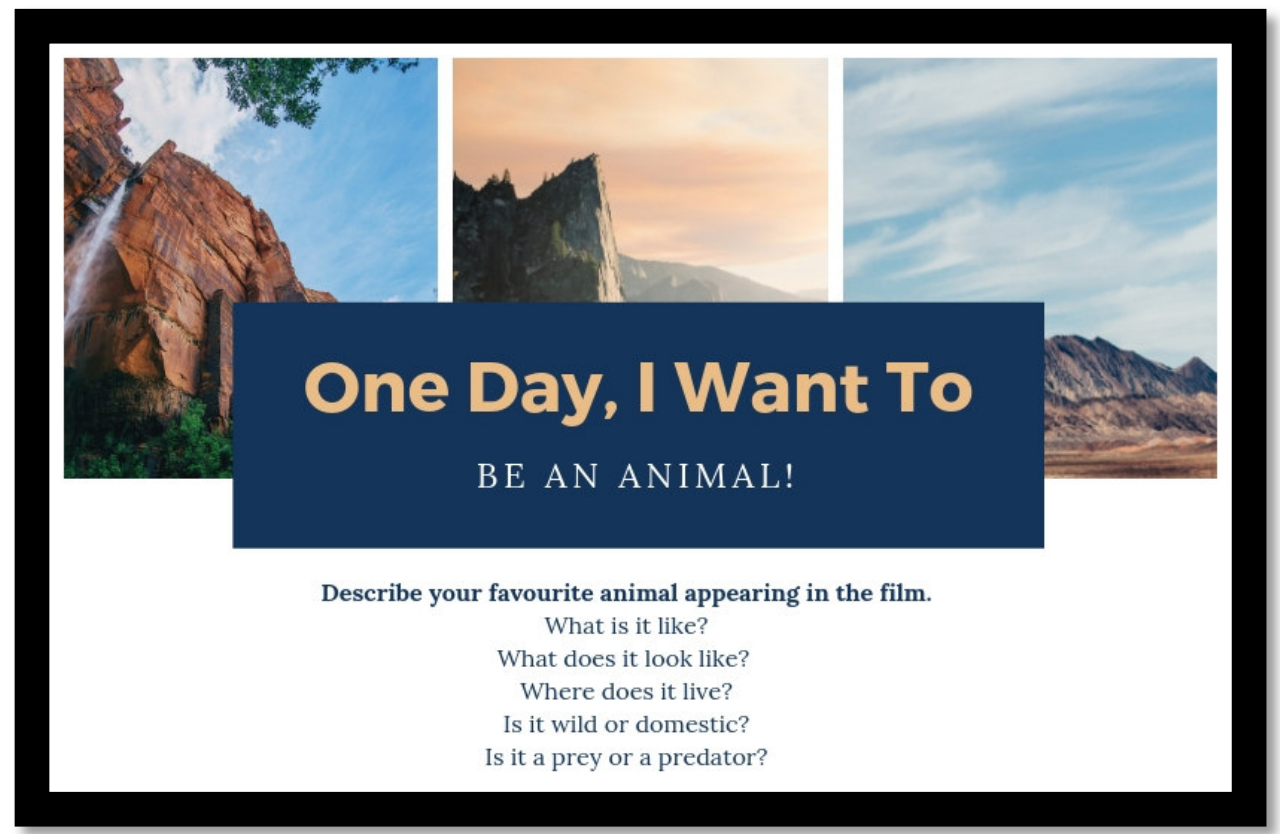

Figure 2. One day I want to be an animal. The above figure presents the proposed questions for students to describe their favourite animal appearing in the film 'Zootopia' during the fifth session.

The spatial and naturalist intelligences are worked in session number six. Pupils should create mind maps classifying preys and predators into their ecosystems. In groups each one has a role, one is in charge of classifying preys and predators, another one is responsible for collecting the different districts from the film, the third one is in charge of connecting the districts with the ecosystems and the fourth one is in charge of joining the animals with their ecosystems. It is recommendable if possible, to use computers or laptops to look for examples of mind maps. Then, they should show it to the rest of their classmates telling them what they did. Consequently, the cooperative learning approach is being executed.

During the seventh session, the naturalist and interpersonal intelligences are developed. Students should complete and activity for classifying the characters according to what they eat. In order to be a cooperative activity, they cannot use their own colours, so they should ask their classmates to lend them their colours. Afterwards, they should do an activity called 'Look through the window' in which pupils should look through the window and take notes about the animals they see. As a result of the interaction between students, the cooperative learning approach is being applied. 


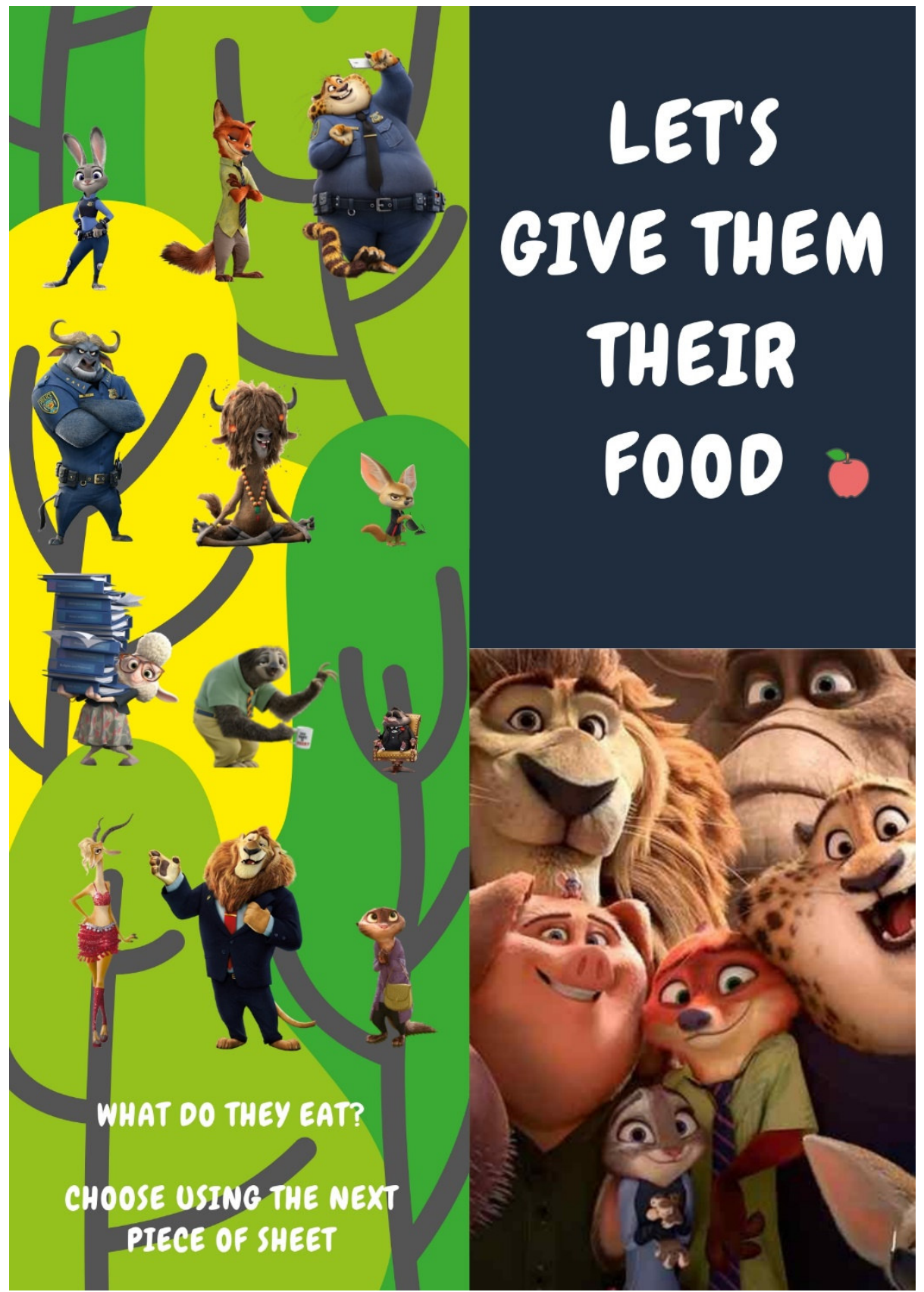

Figure 3. Let's give them their food. The above figure displays an example for classifying the animals according to their food. 


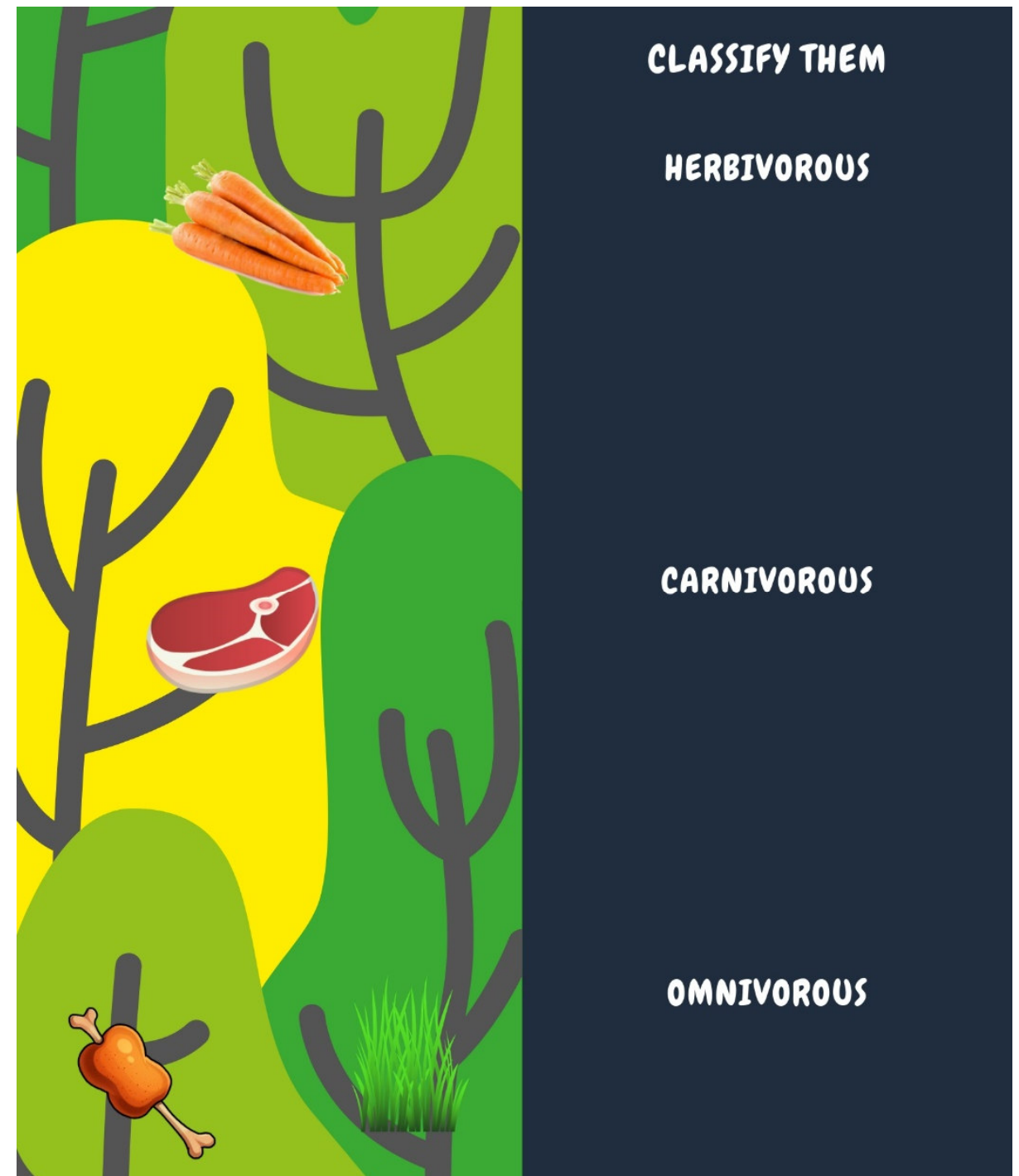

Figure 4. Classification of animals. The above figure exposes the classification into herbivorous, carnivorous and omnivorous for session number seven.

In order to work the intrapersonal intelligence, during the eighth session a brainstorming about the different feelings and emotions appearing in the film should be made. Then, in groups of three students, pupils should create a short story with the emotion, feeling or value they choose, and they should tell their classmates the story. As cooperation between pupils is needed throughout this session, the cooperative learning approach is being implemented.

To finish working on the film, the ninth session is created to develop the musical intelligence. Firstly, pupils should listen to the soundtrack two times and then, they should fill in the gaps using the webpage called 'Lyricstraining' which allow them to practice listening completing the soundtrack of the film, or, in case teachers do not have access to the webpage, they could print the lyrics with some gaps. Finally, every group should create a movement, for example, clapping, standing, rising our hands or moving their arms as if they were snakes. Thus, they should join every movement to a specific word of the soundtrack. In groups, they should perform the dance. In this session, the cooperative learning, design thinking, and total physical response methodologies are involved because of their teamwork and coordination to create gestures, since the pupils' interest is taken into consideration.

The tenth session is produced to check students' improvements, they should answer again the checklist provided by Michael Berman (2002) to know what type of intelligence is better developed in students.

\subsection{Evaluation}

Since this project is interdisciplinary, we are going to assure the assessment of the criteria belonging to different subjects. The fields involved, English, natural sciences, social and civic values, artistic education and physical education, will need a coordination among the different teachers. The evaluation instruments proposed, include, rubrics, tests and co-evaluation techniques.

The rubrics are going to assess the students answer to the questions, writing from one to five sentences with 
a correct use of grammar and vocabulary about topics worked in class (health, daily activities and hobbies, jobs and occupations, the time or their needs).

The evaluation is based on the Common European Framework of Reference for Languages (CEFRL) set of benchmarks for language proficiency. Five different skills are identified: listening, spoken interaction, spoken production, reading and writing. These skills are evaluated within the level A1 Breakthrough. According to the CEFR, pupils who reach the A1 level: can understand and use familiar everyday expressions and very basic phrases aimed at the satisfaction of needs of a concrete type, can introduce him/herself and others and can ask and answer questions about personal details such as where he/she lives, people he/she knows and things he/she has, and can interact in a simple way provided the other person talks slowly and clearly and is prepared to help.

Throughout the third session the writing skill is evaluated in a creative activity in which students should create an end for the film 'Zootopia'. Furthermore, the writing skill is evaluated as well during the fourth session in which pupils should complete their film reviews. Besides, the writing skill is also developed during the fifth session when describing their favourite animal appearing in the film. Thus, these sessions are evaluated through an evaluation rubric.

\begin{tabular}{|c|c|c|c|c|c|}
\hline & 1 & 2 & 3 & 4 & 5 \\
\hline $\begin{array}{l}\text { Third session } \\
\text { Writing }\end{array}$ & $\begin{array}{l}\text { Can write at } \\
\text { least one } \\
\text { sentence in } \\
\text { order to create a } \\
\text { short, simple } \\
\text { end for the film. }\end{array}$ & $\begin{array}{l}\text { Can write at } \\
\text { least two } \\
\text { sentences in } \\
\text { order to create a } \\
\text { short, simple } \\
\text { end for the film. }\end{array}$ & $\begin{array}{l}\text { Can write at } \\
\text { least three } \\
\text { sentences in } \\
\text { order to create a } \\
\text { short, simple } \\
\text { end for the film. }\end{array}$ & $\begin{array}{l}\text { Can write at } \\
\text { least four } \\
\text { sentences in } \\
\text { order to create a } \\
\text { short, simple } \\
\text { end for the film. }\end{array}$ & $\begin{array}{l}\text { Can write at } \\
\text { least five } \\
\text { sentences in } \\
\text { order to create a } \\
\text { short, simple } \\
\text { end for the film. }\end{array}$ \\
\hline $\begin{array}{l}\text { Fourth session } \\
\text { Writing }\end{array}$ & $\begin{array}{l}\text { Can write at } \\
\text { least one } \\
\text { sentence in each } \\
\text { section in order } \\
\text { to complete the } \\
\text { film review in a } \\
\text { short, simple } \\
\text { way. }\end{array}$ & $\begin{array}{l}\text { Can write at } \\
\text { least two } \\
\text { sentences in } \\
\text { each section in } \\
\text { order to } \\
\text { complete the } \\
\text { film review in a } \\
\text { short, simple } \\
\text { way. }\end{array}$ & $\begin{array}{l}\text { Can write at } \\
\text { least three } \\
\text { sentences in } \\
\text { each section in } \\
\text { order to } \\
\text { complete the } \\
\text { film review in a } \\
\text { short, simple } \\
\text { way. }\end{array}$ & $\begin{array}{l}\text { Can write at } \\
\text { least four } \\
\text { sentences in } \\
\text { each section in } \\
\text { order to } \\
\text { complete the } \\
\text { film review in a } \\
\text { short, simple } \\
\text { way. }\end{array}$ & $\begin{array}{l}\text { Can write at } \\
\text { least five } \\
\text { sentences in } \\
\text { each section in } \\
\text { order to } \\
\text { complete the } \\
\text { film review in a } \\
\text { short, simple } \\
\text { way. }\end{array}$ \\
\hline $\begin{array}{l}\text { Fifth session } \\
\text { Writing }\end{array}$ & $\begin{array}{l}\text { Can write the } \\
\text { answer to at } \\
\text { least one } \\
\text { question in a } \\
\text { short, simple } \\
\text { way. }\end{array}$ & $\begin{array}{l}\text { Can write the } \\
\text { answer to at } \\
\text { least two } \\
\text { questions in a } \\
\text { short, simple } \\
\text { way. }\end{array}$ & $\begin{array}{l}\text { Can write the } \\
\text { answer to at } \\
\text { least three } \\
\text { questions in a } \\
\text { short, simple } \\
\text { way. }\end{array}$ & $\begin{array}{l}\text { Can write the } \\
\text { answer to at } \\
\text { least four } \\
\text { questions in a } \\
\text { short, simple } \\
\text { way. }\end{array}$ & $\begin{array}{l}\text { Can write the } \\
\text { answer to at } \\
\text { least five } \\
\text { questions in a } \\
\text { short, simple } \\
\text { way. }\end{array}$ \\
\hline
\end{tabular}

Table 1. Evaluation rubric.

The above table represents the items evaluated during the third, fourth and fifth sessions which are evaluated using the values from 1 to 5, being 1 the value that represents the lower grade of achievement and 5 the highest grade of achievement.

Spoken production is evaluated in the sixth session in which pupils should create their mind maps in a cooperative way and then, show it to the rest of their classmates telling them what they did. This session is evaluated through the below evaluation rubric.

\begin{tabular}{|c|c|c|c|c|c|}
\hline & 1 & 2 & 3 & 4 & 5 \\
\hline $\begin{array}{l}\text { Sixth session } \\
\text { Spoken } \\
\text { production }\end{array}$ & $\begin{array}{l}\text { Can use a word } \\
\text { to describe what } \\
\text { they did. }\end{array}$ & $\begin{array}{l}\text { Can use one or } \\
\text { two words to } \\
\text { describe what } \\
\text { they did. }\end{array}$ & $\begin{array}{l}\text { Can use one } \\
\text { simple phrase } \\
\text { or sentence to } \\
\text { describe what } \\
\text { they did. }\end{array}$ & $\begin{array}{l}\text { Can use two } \\
\text { simple phrases } \\
\text { and sentences } \\
\text { to describe } \\
\text { what they did. }\end{array}$ & $\begin{array}{l}\text { Can use three } \\
\text { simple phrases } \\
\text { and sentences } \\
\text { to describe } \\
\text { what they did. }\end{array}$ \\
\hline
\end{tabular}

Table 2. Evaluation rubric.

The above table represents the items evaluated during the sixth session which is evaluated using the values from 1 to 5, being 1 the value that represents the lower grade of achievement and 5 the highest grade of achievement. The purpose of the seventh session is to promote spoken interaction between pupils, so an evaluation control list is proposed. This control list is helpful for knowing the presence or lack of any characteristic. In this case, the punctuation proposed is from 1 to 5 depending on the number of questions they have asked or answered. 


\begin{tabular}{|l|c|}
\hline & \multicolumn{1}{|c|}{$\begin{array}{c}\text { Seventh session } \\
\text { Spoken interaction }\end{array}$} \\
\hline 'Can I borrow...?' & \\
\hline 'Can you lend me...?' & \\
\hline 'Yes, here you are!' & \\
\hline 'No, sorry' & \\
\hline 'Thank you!' & \\
\hline
\end{tabular}

Table 3. Evaluation control list.

The above table represents the items evaluated during the seventh session which is evaluated according to the number of questions or answers students have used. They can reach values from 1 to 5 , being 1 the value that represents the lower grade of achievement and 5 the highest grade of achievement.

Throughout the eighth session, writing is evaluated at the time pupils should write a breve story including an emotion or feeling they choose. A self-evaluation checklist is proposed which could adapted in order to be used through the online webpage 'Plickers'.

\begin{tabular}{|l|c|}
\hline & $\begin{array}{c}\text { Eighth session } \\
\text { Writing }\end{array}$ \\
\hline I can identify the characters in my story. & \\
\hline I can write the time when the story takes place. & \\
\hline I can write the place where the story happens. & \\
\hline I can identify the emotion or feeling in my story. & \\
\hline I can write an end for mi story. & \\
\hline
\end{tabular}

Table 4. Evaluation checklist.

The above figure represents a self-evaluation checklist proposed for the eighth session in which pupils should mark if they can do or they cannot do the above items. Depending on the number of things they can do, they can reach a total of five points out of five.

The ninth session is prepared to work the listening comprehension. Pupils should listen to the soundtrack of the watched film completing the gaps with the missing words. But also, they should listen to it carefully as it is proposed to create a movement that represents some parts of the soundtrack. In this case, a co-evaluation target between pupils is suggested. In groups, pupils should colour the target according to the behaviour, interest and cooperation shown by another group.

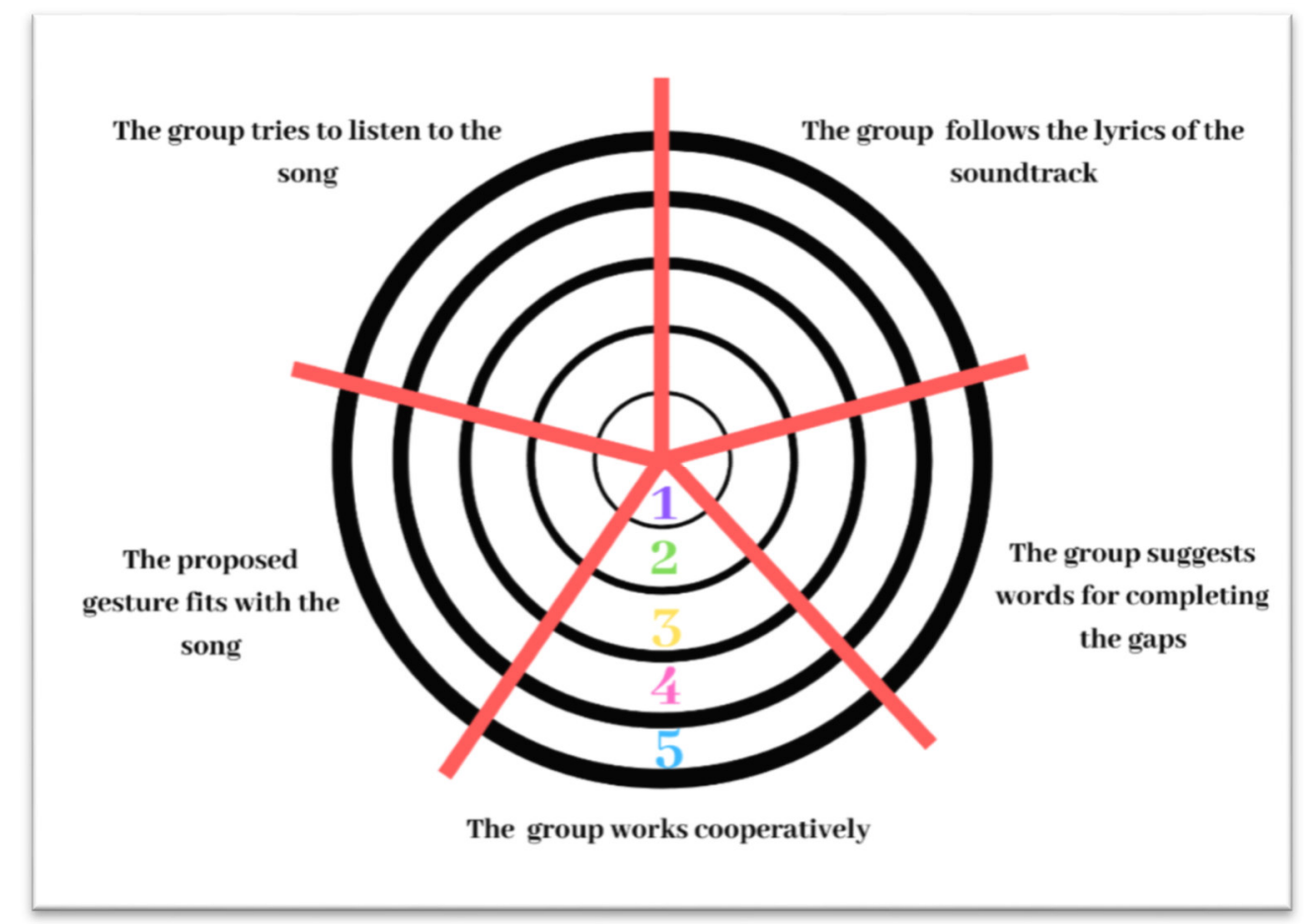

Figure 5. Evaluation target. The above figure exposes the co-evaluation target proposed to evaluate the ninth session. In groups, pupils should evaluate another group colouring the target depending on the above items. Source. Self-elaboration, 2019 


\section{Conclusion}

Adapting the teaching-learning process to the student's abilities poses a challenge to teachers. Being aware of this should determine the use of teaching methods that can seize the potential of pupils as learners. Schools are part of society and must, therefore, be able to contribute with solutions to the challenges coming from a society in permanent change.

Each pupil is different from one another, that is why, their learning should be achieved in an equal way although they have different learning styles. Facing these differences is part of everyday situations we can find in the classrooms.

Thus, the multiple intelligence theory provides us additional knowledge to overcome these situations. It is stated that everyone is intelligent in certain fields, and every possible intelligence should be developed. Pupils should be able to be a whole developed adult. They should know not only about mathematics or languages, but they should also learn how to move around, how to interact with others or how to appreciate music.

Applying the insight of Howard Gardner's theory to school education, and more specifically to project-based learning implies providing an interdisciplinary network that can give our students the resources to develop their skills in an active way. In this way, we can teach English to our students in an engaging way and share contents, methodology and aspects related to evaluation with other subjects. This will help the students to integrate the new knowledge in a more realistic way and enhance their metacognitive skills and competences.

Implementing this proposal could set the basis for further empirical research, showing its potential related to applying MI in teaching backgrounds where films are the core methodological strategy. It also, could determine the several outcomes it can provide in a practical way. Its future development could display the advancement of new possible integrations of the intelligences, due to the arrival and the improvement of new technologies in the field of education.

\section{References}

Alghamdy, R. Z. (2019). EFL Learners' Reflections on Cooperative Learning: Issues of Implementation. Theory \& Practice in Language Studies, 9(3), 271-277.

Armstrong, T., \& Association for Supervision and Curriculum Development. (2009). Multiple Intelligences in the Classroom (Vol. 3rd ed). Alexandria, Va: Assoc. for Supervision and Curriculum Development.

Blasco, P. G., Moreto, G., Blasco, M. G., Levites, M. R., \& Janaudis, M. A. (2015). Education through Movies: Improving Teaching Skills and Fostering Reflection among Students and Teachers. Journal for Learning through the Arts, 11(1).

Breeze, R. (2014). Integration of Theory and Practice in CLIL. Amsterdam: Brill | Rodopi.

Breu, R., \& Ambrós, A. (2011). El cine en la escuela.: propuestas didácticas de películas para primaria y secundaria. Barcelona: Graó, 2011.

Champoux, J. E. (2005). Comparative analyses of live-action and animated film remake scenes: finding alternative film-based teaching resources. Educational Media International, 42(1), 49-69.

Council of Europe. Council for Cultural Co-operation. Education Committee. Modern Languages Division. (2001). Common European Framework of Reference for Languages: learning, teaching, assessment. Cambridge University Press.

Gardner, H. (1993). Multiple intelligences: the theory in practice. New York: BasicBooks, cop. 1993.

Gardner, H. (1999). Intelligence reframed: multiple intelligences for the 21st century. New York: Basic Books, cop. 1999.

https://es.lyricstraining.com/play/shakira/try-everything-audio/HbW8nMdlLb\#ibw

Johnson, D. W., \& Johnson, R. T. (1999). Learning together and alone: Cooperative, competitive, and individualistic learning. Boston: Allyn \& Bacon.

Kabooha, R. H. (2016). Using Movies in EFL Classrooms: A Study Conducted at the English Language Institute (ELI), King Abdul-Aziz University. English Language Teaching, 9(3), 248-267.

Kenna, J. L. \& Waters, S. (2017). Teaching Geography through an Animated Lens. Clearing House, 90(4), 147151.

Willness, C., \& Bruni-Bossio, V. (2017). The Curriculum Innovation Canvas: A Design Thinking Framework for the Engaged Educational Entrepreneur. Journal of Higher Education Outreach and Engagement, 21(1), 134164

Żebrowski, M. (2017). Educational Potential of Animated Films in Poland. Panoptikum, 25(18), $106-119$.

Zulpan Zulpan. (2018). Total Physical Response (TPR): Its Effect on Students' Achievement in Reading Procedure Text. JEES (Journal of English Educators Society), (2), 205. 